\title{
Patterns of gall infestation in Heteropterys byrsonimifolia A. Juss. in a forest-savannah ecotone
}

\author{
Marcela de Castro Nunes Santos Terra ${ }^{1 *}$, Rubens Manoel dos Santos ${ }^{1}$, Warley Augusto Caldas Carvalho ${ }^{1}$, \\ Polyanne Aparecida Coelho ${ }^{1}$, Geovany Heitor Reis ${ }^{1}$, Aline Martins Moreira ${ }^{1}$
}

10.1590/0034-737X201764020006

\begin{abstract}
Galls are the result of a specific interaction between an inducer and a host plant. The species Heteropterys byrsonimifolia A. Juss. occurs in abundance in semideciduous seasonal forest ecotones and adjacent open formations. In the ecological reserve Quedas do Rio Bonito, located in the state of Minas Gerais, Brazil, this species is affected by a single gall morphotype. The present study aimed to evaluate whether the structural complexity of the host (test of the structural complexity hypothesis) and the distance between hosts (test of the resource concentration hypothesis) affect gall density in $H$. byrsonimifolia and to characterize the spatial distribution of the infestation. The results corroborate the two hypotheses tested, suggesting a metapopulation pattern of gall infestation in $\mathrm{H}$. byrsonimifolia. Gallers were more successful in abrupt forest-savannah transition environments, which may be associated with greater stress-induced host vulnerability that plants usually experience in ecotones.
\end{abstract}

Keywords: insect-plant interaction; ecotone; multiple regression; geostatistics.

\section{RESUMO}

\section{Padrões de infestação por galhas em Heteropterys byrsonimifolia A. Juss., em ecótone floresta-cerrado}

Galhas são resultantes da interação específica entre um indutor e a planta hospedeira. A espécie Heteropterys byrsonimifolia A. Juss. ocorre em abundância em ecótones de floresta estacional semidecidual e formações abertas adjacentes. No Parque Ecológico Quedas do Rio Bonito no estado de Minas Gerais, Brasil, essa espécie é afetada por um único morfotipo de galhas. O presente estudo objetivou avaliar se a complexidade estrutural do hospedeiro (teste da Hipótese da Complexidade Estrutural) e a distância entre hospedeiros (teste da Hipótese da Concentração de Recursos) têm influência sobre a densidade de galhas em $H$. byrsonimifolia, além de caracterizar a espacialização da infestação. Os resultados corroboram as duas Hipóteses testadas, sugerindo um comportamento metapopulacional das galhas em $H$. byrsonimifolia. Encontrou-se também um maior sucesso dos galhadores em ambientes de transição abrupta entre floresta-cerrado, o que pode estar associado à maior vulnerabilidade dos hospedeiros ocasionados por estresse que as plantas usualmente sofrem em ambientes ecotonais.

Palavras-chave: interação inseto-planta; ambiente ecotonal; regressão múltipla; geoestatística.

\footnotetext{
Submitted on March 25th, 2014 and accepted on February 11th, 2017.

${ }^{1}$ Universidade Federal de Lavras, Departamento de Ciências Florestais, Lavras, Minas Gerais, Brasil. rubensmanoel@dcf.ufla.br; warleycaldas@dcf.ufla.br; pcoelho.ufla@gmail.com; geovanyreis@gmail.com; aline.martinsmoreira@gmail.com

*Autora para correspondência: marcelacns@gmail.com
} 


\section{INTRODUCTION}

Effective conservation measures for biota should take into account not only the diversity of species but also the functional diversity of ecosystems (Santos et al., 2012), which includes biotic and abiotic interactions. Ecological interactions elucidate evolutionary and co-evolutionary paths (Jordano et al., 2003; Agrawal et al., 2012; Forister et al., 2012) and provide numerous ecosystem services, such as pollination (Kaiser-Bunbury et al., 2010) and dispersion (Jordano et al., 2003). Interactions considered "disharmonic", such as herbivory, predation, competition and parasitism, also play important roles, especially in controlling antagonistic populations (Van der Putten et $a l ., 2001)$ and deserve to be investigated to elucidate the determinant parameters in these processes.

Galls are the result of an interaction between an inducer and its host, which causes morphological changes in plant tissues or organs, resulting in hypertrophy and hyperplasia of plant cells in response to species-specific stimuli (Mani, 1964; Costa et al., 2010). Galling insects are highly specialized herbivores, making the process of locating the host plant vital for the colonization of certain sites. The populations of these insects are regulated, and their performance is affected by variations in the host plant, such as the variability among plants of the same species and variation within the same plant (Hunter et al., 1992; Fagundes et al., 2001). Thus, the occurrence of these herbivores is generally affected by the size of individuals and the spatial distribution of host plants (Strong et al., 1984), which are representative attributes of the abundance of oviposition resources.

Regarding plant size, the plant architecture hypothesis (Lawton, 1983) predicts that structurally more complex plants offer more microhabitats and therefore support larger populations of herbivores. In this sense, allometric relationships, i.e., plant size to shape relationships, in addition to reflecting the adaptive strategies of plants (Niklas, 1994), provide an idea of the structural complexity of the individuals and consequently of the exposure of individuals to the action of herbivores. In turn, the resource concentration hypothesis (Root, 1973) predicts that resource patches with more concentrated spatial distributions must have a greater abundance of herbivores, that is, there is an effect of host plant density on the abundance and parasitism of galls.

In addition to these factors, there is the effect of environmental heterogeneity. Gallers have different distributions, which depend on the habitat and vegetation type (Gonçalves-Alvim \& Fernandes, 2001; Mendonça et al., 2010; Araújo \& Guilherme, 2012). Investigating the effects of landscape on the density of galling insects is an important way to clarify these patterns in changing ecosystems. In this sense, both the landscape complexity and the type of matrix can alter the occurrence of galling insects (Araújo \& Guilherme, 2012). This point is somewhat obscure because most studies that address the ecology of the plant-gall interaction address local patterns (a single environment), and of these, most studies in Brazil are concentrated in the Brazilian Savannah (e.g., Lara et al., 2008; Costa et al., 2010). Few studies address interactions of this nature in ecotones, where a mixture of vegetation from adjacent and different formations occurs. Ecotones are very peculiar environments because they are located in the transition zone between two ecosystems, with several implications for the organisms that inhabit them.

The documentation and elucidation of biodiversity patterns are essential for the conservation of plant and insect species. The close and highly specialized gallerplant relationship makes gallers more susceptible to local environmental changes. Consequently, gallers can be used as bioindicators (Fernandes et al., 1995) and tools in environmental quality studies (Julião et al. 2005). In this context, the objectives of the present study were (a) to evaluate whether the structural complexity of an individual host (test of the structural complexity hypothesis) and the distance between hosts (test of the resource concentration hypothesis) affect the density of galls in a forest-savannah ecotone and (b) to analyze the spatial configuration of the infestation to identify sites of high galler success. It was expected that more structurally complex individuals will have higher gall density, that gall density is spatially dependent, and gallers are more successful in the savannah than in forested areas.

\section{MATERIALS AND METHODS}

\section{Host species studied}

Heteropterys byrsonimifolia A. Juss. is an arboreal Malpighiaceae, popularly known in Brazil as "Murici-macho", abundant in the state of Minas Gerais, and is frequently found in Brazilian savannah formations (Mendonça et al., 1998), seasonal semideciduous forests (Oliveira-Filho et al., 1994; Carvalho et al., 2005) and seasonal deciduous forests (Nunes et al., 2006). The leaves of $H$. byrsonimifolia are simple, decussate and elliptical, and at the study site, they were infested with a single gall morphotype on the adaxial side. The galling insect was not identified, but field observations pointed to the order Diptera.

\section{Study site and data collection}

The study was carried out in an ecotonal area between the savannah sensu stricto (woodland savannah) and a semi-deciduous seasonal forest in the ecological reserve Quedas do Rio Bonito, located in La- 
vras, Minas Gerais, Brazil, with coordinates $21^{\circ} 20^{\prime} 09^{\prime \prime S}$ and $44^{\circ} 58^{\prime} 49^{\prime \prime} \mathrm{W}$ (Figure 1A).

Sampling was carried out in a specific area of approximately $1,500 \mathrm{~m}^{2}$, where 50 individuals of $H$. byrsonimifolia were randomly sampled and identified in the field by an expert (Figures 1B and 1C). The Cartesian coordinates of the individuals in the field were recorded using tape measures. To characterize the structural complexity of the hosts, the total height (linear distance between the ground and the top of the crown), crown height (vertical distance between the lowest leaf and the top of the crown) and crown diameter (greatest horizontal crown length) of the trees were measured using a tape measure. The circumference at ground level (CGL, later transformed into diameter at ground level - DGL) was also measured using a tape measure. To measure gall density, three branches were collected from each individual, one in the lower third of the crown (lower stratum), one in the middle third of the crown (intermediate stratum) and one in the upper third of the crown (upper stratum), yielding a total of 150 branches. These branches were collected randomly from each strata. Each branch was stored in a plastic bag and transported to the laboratory to count the number of galls and number of leaves per branch.

\section{Data analysis}

For each branch collected, the gall density (number of galls per number of leaves) was calculated to avoid the possible influence of differences in the number of leaves per branch. From the measurements performed on each $H$. byrsonimifolia individual, allometric ratios were calculated to characterize the structural complexity of the individuals (Table 1). The differences in gall density per stratum were assessed using analysis of variance (ANOVA), followed by Tukey test. The correlations between gall density and structural complexity were tested using multiple linear regressions of the total gall density and gall density per stratum as a function of the allometric ratios considered. Significance was assessed using a t-test conducted on the parameters associated with each variable. To guarantee the assumptions of the regression, the variables density, height, individual slenderness, crown depth and crown slenderness were $\log _{10}$-transformed.

To evaluate whether $H$. byrsonimifolia individuals located closer to each other had similar gall densities, geostatistics based on theoretical spatial models were used (Journel \& Huijbregts, 1978). We thus tested the spatial dependence of the total host gall density variable and the spatial dependence of each of the three vertical strata considered. For this purpose, an experimental semivariogram was generated for each situation considered (total gall density per host and per stratum) and, in the presence of spatial structuring of the data, the fits of three theoretical spatial models (exponential, spherical and Gaussian) were tested using the least squares method. For each situation, the best model was selected based on the degree of spatial dependence (DSD) (Mello et al., 2008).

Table 1: Measurements and allometric ratios used to characterize the structural complexity of individuals of Heteropterys byrsonimifolia in an ecotone between a semideciduous seasonal forest and Brazilian savannah in Minas Gerais state, Brazil

\begin{tabular}{ll}
\hline Measurement or Relation: & \multicolumn{1}{c}{ Given by: } \\
\hline Total height & (direct measurement) \\
Individual slenderness & (total height) / DGL \\
Crown depth & (crown height) / (total height) \\
Crown slenderness & (crown depth)/ (crown diameter) \\
\hline
\end{tabular}

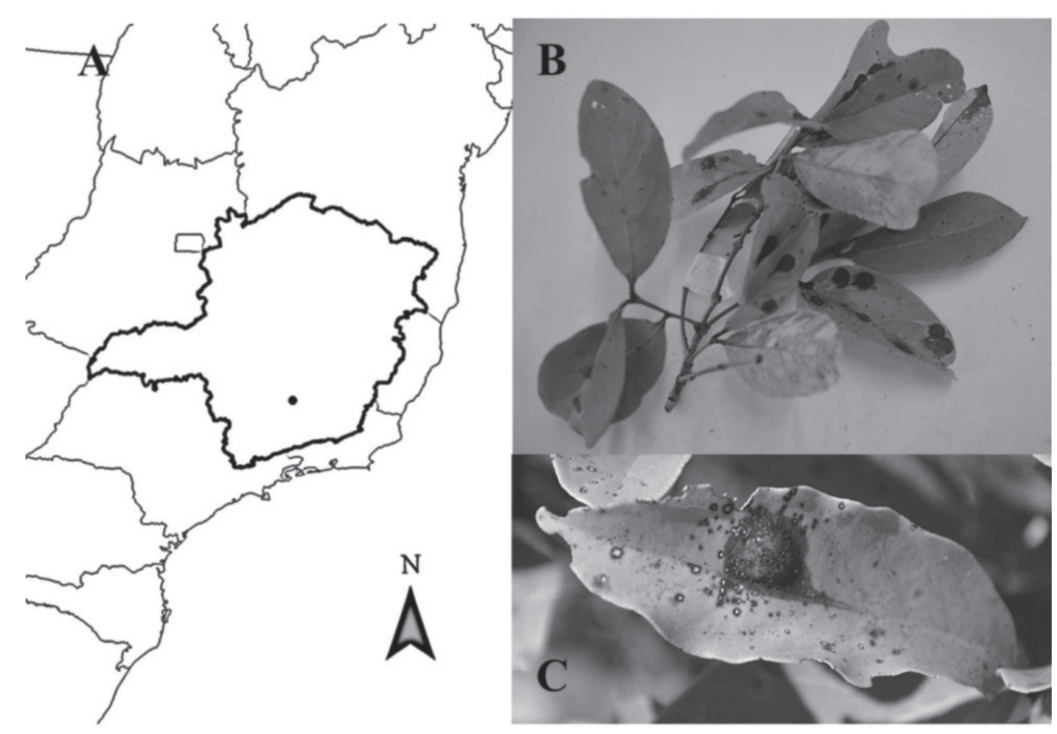

Figure 1: (A) Location of the municipality of Lavras, where the ecological reserve of Quedas do Rio Bonito (study site) is located, in the state of Minas Gerais, Brazil; (B) Heteropterys byrsonimifolia sample branch collected and (C) gall morphology detail. 
Bubble graphs of the total gall densities and density per stratum (with $1 n+1$ transformation for scale standardization) were constructed using the Cartesian coordinates (in meters), collected in the field, presented on the $\mathrm{X}$ and $\mathrm{Y}$ axes. In addition, the total gall density was plotted on the study site map for visual analysis of the spatial distribution of infestation. All analyses were performed using the $\mathrm{R}$ platform ( $\mathrm{R}$ Development Core Team, 2010), and spatial analyses were performed using the geoR package (Ribeiro-Junior \& Diggle, 2001).

\section{RESULTS}

The overall mean gall density was $0.29 \mathrm{~g} / \mathrm{leaf}$. In the upper stratum, the mean gall density was $0.4 \mathrm{~g} / \mathrm{leaf}$ compared with $0.32 \mathrm{~g} / \mathrm{leaf}$ in the intermediate stratum and $0.15 \mathrm{~g} / \mathrm{leaf}$ in the lower stratum. The analysis of variance results indicated significant differences $(p=0.0059)$ in the gall densities among the strata of the sampled individuals, and the Tukey test indicated differences $(p<0.01)$ between the means of the upper and lower strata, that is, the upper stratum had significantly higher gall density than the lower stratum.

The multiple linear regression of total gall density as a function of the measurements and allometric ratios of the host revealed significance $(\mathrm{p}<0.1)$ of the parameters associated with the variables height, crown depth and crown slenderness. For the strata, only the parameter associated with crown slenderness in the lower stratum was significant $(\mathrm{p}<0.1)$ (Table 2 ). It should be noted that in all cases, the parameter associated with the height variable, although not significant for the strata, was negative, indicating that for all situations, the greater the height, the lower the density of galls. The same was true for crown slenderness: the deeper the crowns are in relation to their diameters, the lower the density of galls.
On the other hand, analysis of the parameters related to an individual's slenderness and crown depth, which were not significant in most cases, revealed a trend toward higher gall density in slender individuals and in those with deeper crowns.

All the strata considered presented a strong spatial dependence, which was reflected by the high spatial dependence of the total density of galls per tree (DSD = $84.17 \%$ ). The lower stratum was characterized by a degree of spatial dependence equal to $100 \%$, followed by the intermediate stratum (DSD $=92.99 \%$ ). The upper stratum exhibited the weakest spatial dependence, i.e., $77.04 \%$. The theoretical spatial model selected in all cases was the Gaussian, with the exception of the lower stratum,
A

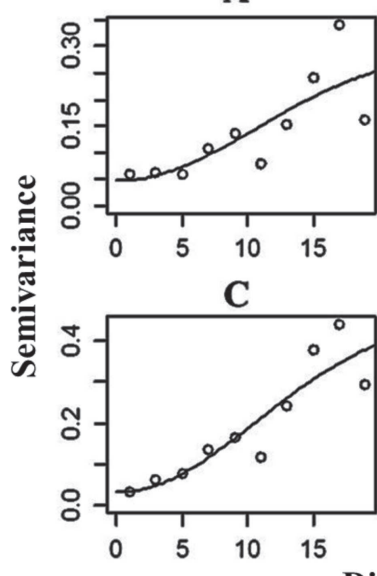

B

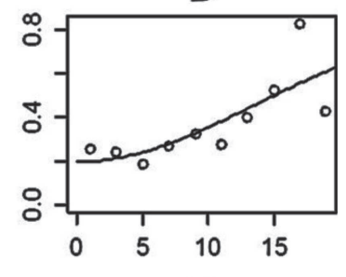

D

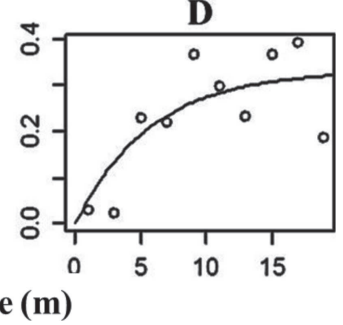

Figure 2: Experimental semivariograms of gall density in Heteropterys byrsonimifolia individuals in an ecotone between a semideciduous seasonal forest and savannah in Minas Gerais, Brazil, with fitted theoretical spatial models: (A) total gall density per tree; (B) gall density in the upper tree stratum; (C) gall density in the intermediate tree stratum; and (D) gall density in the lower tree stratum.

Table 2: Parameter values of the multiple linear regressions of gall density in individuals of Heteropterys byrsonimifolia in an ecotone between a semideciduous seasonal forest and Brazilian savannah in Minas Gerais, Brazil, as a function of explanatory variables, tested using a t test

\begin{tabular}{|c|c|c|c|c|c|c|c|c|}
\hline & & Intercept & Height & $\begin{array}{l}\text { Individual } \\
\text { slenderness }\end{array}$ & $\begin{array}{l}\text { Crown } \\
\text { depth }\end{array}$ & $\begin{array}{c}\text { Crown } \\
\text { slenderness }\end{array}$ & $R^{2}$ & Syx \\
\hline \multirow{2}{*}{ Total } & Par. & 0.370 & -0.424 & 0.865 & 0.967 & -1.197 & \multirow{2}{*}{10.66} & \multirow{2}{*}{0.229} \\
\hline & $p$ & 0.314 & 0.078 & 0.118 & 0.079 & 0.028 & & \\
\hline \multirow{2}{*}{ US } & Par. & 0.231 & -0.416 & 1.073 & 1.126 & -1.118 & \multirow{2}{*}{6.14} & \multirow{2}{*}{0.317} \\
\hline & $p$ & 0.370 & 0.207 & 0.158 & 0.138 & 0.133 & & \\
\hline \multirow{2}{*}{ IS } & Par. & 0.564 & -0.461 & 0.258 & 1.022 & -0.936 & \multirow{2}{*}{11.82} & \multirow{2}{*}{0.039} \\
\hline & $p$ & 0.203 & 0.110 & 0.695 & 0.122 & 0.148 & & \\
\hline \multirow{2}{*}{ LS } & Par. & 0.238 & -0.241 & 0.844 & 0.367 & -1.044 & \multirow{2}{*}{12.4} & \multirow{2}{*}{0.04} \\
\hline & $p$ & 0.523 & 0.320 & 0.133 & 0.508 & 0.059 & & \\
\hline
\end{tabular}

p-values significant at the 0.1 level are shown in bold.

Total: Total gall density per individual; US: Density in the upper stratum of an individual; IS: Density in the intermediate stratum of an individual; LS: Density in the lower stratum of an individual; Par: Parameter estimates; R²: Coefficient of determination; Syx: Residual standard error

Rev. Ceres, Viçosa, v. 64, n.2, p. 143-150, mar/abr, 2017 
which was better represented by an exponential model (Figure 2).

When plotting the total gall density on the hosts on the study site map (Figure 3), it was possible to observe higher gall density at the forest edges, in the abrupt transition to the savannah.

\section{DISCUSSION}

In general, four basic sources of variation affect herbivore population patterns: (1) presence or absence of host plants; (2) temporal variation in plant resources; (3) variability among plants of the same species; and (4) variation within the same plant (Hunter et al., 1992; Fagundes et al., 2001). Thus, preference for individuals within the host species, or for specific characteristics of the individuals, has been reported in the literature (Lara $e t$ al., 2008; Espírito-Santo et al., 2007), although the abundance of herbivorous insects naturally occurring in conspecific hosts is often very variable (Fagundes \& Gonçalves, 2005).

In the present case, in general terms, the density of galls on branches responded to the structural complexity of the H. byrsonimifolia individuals, and there was spatial dependence of gall density in individuals of this species. In general, gall density was higher in shorter individuals, with a greater crown depth and not very narrow crowns.
That is, a higher crown volume was a decisive parameter - more than the total height per se - for gall density in the studied $H$. byrsonimifolia population. Greater canopy volume implies more meristems, and because galling insects depend on undifferentiated young tissues for induction and development, a high abundance of galls should be expected under high structural complexity (Espírito-Santo et al., 2007). In this sense, the high availability of meristems explains high colonization in more architecturally complex plants because of increased oviposition sites (Lara et al., 2008). In addition, greater structural complexity may mean more enemy-free areas for insects, as predicted by the enemy-free space hypothesis (Berdegue et al., 1996).

The significantly higher gall density in the upper stratum compared to the lower stratum may indicate that greater exposure of an individual affects gall density. Therefore, the analyses performed on the total gall density of individuals of $H$. byrsonimifolia were also performed by stratum (upper, intermediate and lower). However, the patterns were unclear by stratum. When considering the entire individual tree, the density of galls was significantly correlated with total height, crown depth and crown slenderness. However, the per stratum gall density did not reflect or weakly reflected the attributes used to illustrate the structural complexity of $H$. byrsonimifolia

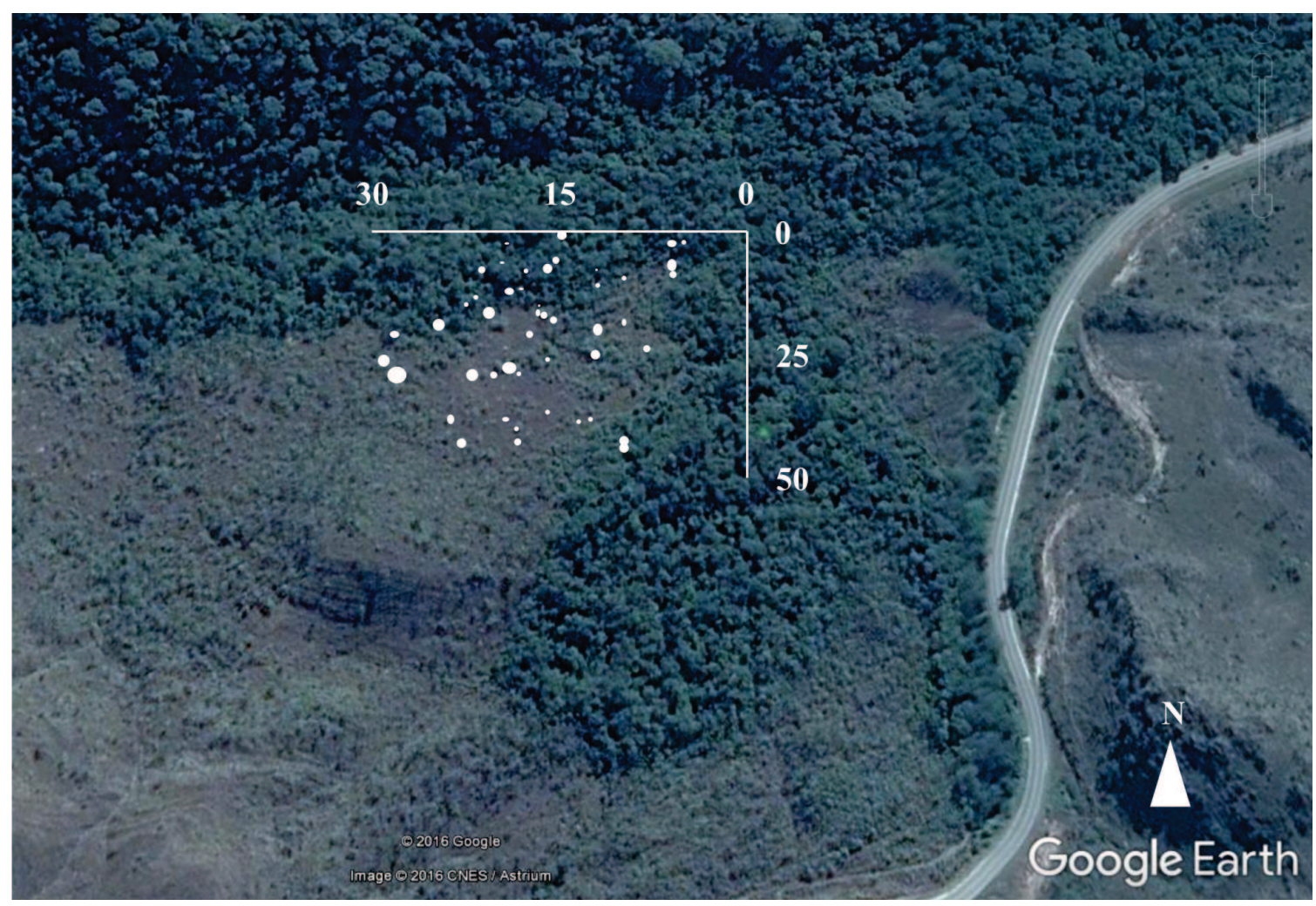

Figure 3: Bubble graph indicating the total gall density ( $\mathrm{ln}+1$ transformed) in individuals of Heteropterys byrsonimifolia in a 1,500 $\mathrm{m}^{2}$ ecotone between a semideciduous seasonal forest and savannah in Minas Gerais, Brazil. (Axes are presented in meters; larger bubbles represent higher gall density). 
individuals (the gall density on the branches reflected the slenderness of the crown only in the lower stratum). Due to the absence of an inclusion criterion in the sampling, the large range of heights considered resulted in extensive variation of stratum conditions. For example, the three strata were very close together in trees with very small crowns, which may have masked patterns. The fact that the strata did not respond to architectural attributes may also have occurred because none of the attributes were stratum-specific; rather, they were related to the whole individual. Specific characteristics not considered, such as the number of branches and stratum biomass, may be highly correlated with stratum gall density (Lara et al., 2008) and may have influenced the results.

The present study corroborates the structural complexity hypothesis for total gall density in the individuals of $H$. byrsonimifolia in the studied population because the physical structure of the shoots of the host plant affected the structure of the population of herbivorous insects (Lawton, 1983). Based on a wide scale, Espírito-Santo et al. (2007) reinforced that plant architecture is usually a relevant factor influencing the distribution and abundance of herbivory, but the determinant characteristics of plants can vary among studies depending on the life history of the species involved. However, this pattern is not always observed. Costa et al. (2010) used principal component analysis to summarize architectural explanatory variables and did not observe a significant relationship between the diversity and abundance of galls associated with Copaifera langsdorffii Desf. in Montes Claros, Minas Gerais, or with the size or pattern of branching of the host plant. According to Fagundes et al. (2001), the lack of correlation suggests that other aspects of the herbivore/plant interaction should be focused on to explain the abundance of galls. Thus, gallers may respond to plant characteristics other than structural complexity, such as meristem dynamics, phenology, resource allocation, growth physiology, and defense mechanisms among architectural types. Therefore, these characteristics could have a more important effect on the diversity of gallers compared with the architecture of the plant (Fernandes et al., 1997; Gonçalves-Alvim \& Fernandes, 2001).

The strong spatial dependence found for the variable gall density in all situations considered shows that $H$. byrsonimifolia individuals located closer to each other had more similar gall densities than more distant individuals, which generally corroborates the resource concentration hypothesis (Root, 1973), that is, closer resource patches should have similar and larger herbivore abundances. However, similar to the structural complexity hypothesis, some studies have not corroborated this hypothesis (e.g., Fagundes et al., 2001).
The fact that the structurally more complex individuals had higher gall density and that the variable gall density was spatially structured leads to a metapopulation approach, in which the configuration of local populations heterogeneously distributed in a habitat is in accordance with the distribution of resources (Hanski, 1997). Thus, each individual tree would be an isolated population, and local and regional processes of extinction and colonization would interact to determine the structure of the total population (Fagundes et al., 2001). Extinction and colonization in this case depend directly on the ability of an adult female to find plants suitable for larval growth and survival because the immature stage limits mobility and the ability to fully exploit the resources of a host plant (Santos et al. 2012). However, it is necessary to monitor this population to elucidate the metapopulation dynamics (Fagundes et al., 2001).

Another point to be considered is the fact that the study site is a forest-cerrado ecotone, with large environmental variations, mainly of edaphic character. Since galls, due to the intimate relationship with the host, exhibit predictable responses to environmental variations (Santos et al., 2012) and plant nutrients in high concentrations become toxic to the gall larvae, the larvae would be more successful in environments under the influence of some stress where the plants tend to exhibit nutritional deficiencies (Carneiro et al., 2009). Thus, the nutritional stress caused by the ecotone may have led to greater gall success in trees located at the forest edge, where low nutrient cycling occurs (Ferreira et al., 2006) and the trees are not yet exposed to the higher concentrations of aluminum present in Brazilian savannah soils (Haridasan, 2000; Klink \& Machado, 2005). Other edaphic changes at the forest-savannah ecotone transition, such as changes in soil drainage (Loschi et al., 2013), as well as microclimatic changes, common to ecotonal environments, also increase the rates of galling insect occurrence, as they increase plant vulnerability to herbivore attack (Araújo et al., 2011; Araújo \& Guilherme, 2012).

\section{CONCLUSIONS}

The present study partially corroborates the structural complexity and resource concentration hypotheses for gall density in individuals of $H$. byrsonimifolia at the study site, suggesting a metapopulation pattern for the gall population. In addition, we observed greater galler success in the abrupt transition zone between the forest and the savannah.

The patterns found, together with studies of the dynamics of these antagonistic populations, may contribute to a deeper understanding of the ecology of ecotones. 


\section{REFERENCES}

Agrawal AA, Hastings AP, Johnson MTJ, Maron LL \& Salminen JP (2012) Insect herbivores drive real-time ecological and evolutionary change in plant populations. Science, 338:113-116.

Araújo WS, Julião GR, Ribeiro BA, Silva IPA \& Santos BB (2011) Diversity of galling insects in Styrax pohlii (Styracaceae): Edge effect and use as bioindicador. Revista de Biologia Tropical, 59:1589-1597.

Araújo WS \& Guilherme FAG (2012) Distribuição de insetos galhadores em diferentes formações vegetais e paisagens do cerrado brasileiro. Bioscience Journal, 8:810-819.

Berdegue M, Trumble JT, Hare JD \& Redak RA (1996) Is it enemyfree space? The evidence for terrestrial insects and freshwater arthropods. Ecological Entomology, 21:203-217.

Carneiro MAA, Branco CSA, Braga CED, Almada ED, Costa MBM, Maia VC \& Fernandes GW (2009) Are gall midge species (Diptera, Cecidomyiidae) host-plant specialists? Revista Brasileira de Entomologia, 53:365-378.

Carvalho DA, Oliveira-Filho AT, Vilela EA, Curi N, Berg EVD, Fontes MAL \& Botezelli L (2005) Distribuição de espécies arbóreo-arbustivas e ao longo de um gradiente de solos e topografia em um trecho de floresta ripária do rio São Francisco em Três Marias, MG, Brasil. Revista Brasileira de Botânica, 28:329-345.

Costa FV, Fagundes MF \& Neves FS (2010) Arquitetura da planta e diversidade de galhas associadas a Copaifera langsdorfûi (Fabaceae). Ecologia Austral, 20:09-17.

Espírito-Santo MM, Neves FS, Andrade-Neto FR \& Fernandes GW (2007) Plant architecture and meristem dynamics as the mechanisms determining the diversity of gall-inducing insects. Oecologia, 153:353-364.

Fagundes M \& Gonçalves CL (2005) Padrão de ataque de um inseto galhador (Diptera: Cecidomyiidae) em Astronium fraxinifolium (Anacardiaceae) em uma Floresta Estacional Decidual. Unimontes Científica, 7:107-114.

Fagundes M, Faria ML \& Fernandes GW (2001) Efeitos da distribuição de Baccharis dracunculifolia (Asteraceae) na abundância e no parasitismo de galhas de Neopelma baccharidis (Homoptera: Psyllidae). Unimontes Científica, 1:97-103.

Fernandes GW, Paula AS \& Loyola Jr. R (1995) Distribuição de insetos galhadores entre habitats e seu possível uso como bioindicadores. Vida Silvestre Neotropical, 4:133-139.

Fernandes GW, Araújo MAA, Carneiro MA, Cornellssen RG, Barcelos-Greco MC, Lara ACF \& Ribeiro S (1997) Padrões de riqueza de insetos em gradientes altitudinais na Serra do Cipó, Minas Gerais. In: $3^{\circ}$ Congresso de Ecologia do Brasil, Brasília. Anais, UnB. p.191-195

Ferreira SJF, Luizão FJ, Miranda SAF, Silva MSR \& Vital ART (2006) Nutrientes na solução do solo em floresta de terra firme na Amazônia Central submetida à extração seletiva de madeira. Acta Amazonica, 36:59-68.

Forister ML, Dyer LA, Singer MS, Stireman III JO \& Lill JT (2012) Revisiting the evolution of ecological specialization, with emphasis on insect-plant interactions. Ecology, 93:981-991.

Gonçalves-Alvim SJ \& Fernandes GW (2001) Comunidades de insetos galhadores (Insecta) em diferentes fisionomias do cerrado em Minas Gerais, Brasil. Revista Brasileira de Zoologia, 18:289-305.

Hanski IA (1997) Metapopulation dynamics: from concepts and observations to preditive models. In: Hanski IA \& Gilpin ME (Eds.) Metapopulation biology: Ecology, genetics, and evolution. San Diego, Academic Press. p.69-91.
Haridasan M (2000) Nutrição mineral de plantas nativas do cerrado. Revista Brasileira de Fisiologia Vegetal, 12:54-64.

Hunter MD, Ohgushi T \& Price PW (1992) Effects of resource distribution on animal-plant interactions. San Diego, Academic Press. 505p.

Jordano P, Bascompte J \& Olesen JM (2003) Invariant properties in coevolutionary networks of plant-animal interactions. Ecology Letters, 6:69-81.

Journel AG \& Huijbregts CJ (1978) Mining Geostatistics. London, Academic Press. 600p.

Julião GR, Fernandes GW, Negreiros D, Bedê L \& Araújo RC (2005) Insetos galhadores associados a duas espécies de plantas invasoras de áreas urbanas e peri-urbanas. Revista Brasileira de Entomologia, 49:97-106.

Kaiser-Bunbury CN, Muff S, Memmott J, Müller CB \& Caflisch A (2010) The robustness of pollination networks to the loss of species and interactions: a quantitative approach incorporating pollinator behaviour. Ecology Letters, 13:442-452.

Klink CA \& Machado RB (2005) A conservação do Cerrado brasileiro. Megadiversidade, 1:147-155.

Lara DP, Oliveira LA, Azevedo IFP, Xavier MF, Silveira FAO, Carneiro MAA \& Fernandes GW (2008) Relationships between host plant architecture and gall abundance and survival. Revista Brasileira de Entomologia, 52:78-81.

Lawton JH (1983) Plant architecture and the diversity of phitophagous insects. Annual Review of Entomology, 28:2339.

Loschi RA, Pereira JAA, Machado ELM, Carlos L, Gonzaga APD, Carmo IP \& Gomes DJS (2013) Variações estruturais e ambientais em um contínuo de mata de galeria/cerrado stricto sensu em Itumirim, MG. CERNE, 19:213-227.

Mani MS (1964) Ecology of Plant Galls. Junk, The Hague. 343p.

Mello CR, Viola MR, Mello JM \& Silva AM (2008) Continuidade espacial de chuvas intensas no estado de Minas Gerais. Ciência e Agrotecnologia, 32:532-539.

Mendonça RC, Felfili JM, Walter BMT, Silva-Júnior MC, Rezende AV, Filgueiras TS \& Nogueira PE (1998) Flora Vascular do Cerrado. In: Sano SM \& Almeida SP (Eds.) Cerrado: ambiente e flora. Planaltina, Embrapa-CPAC. p.289-556.

Mendonça MS, Piccardi HMF, Jahnke SM \& Dalbem R (2010) Galling Arthropod Diversity in Adjacent Swamp Forests and Restinga Vegetation in Rio Grande do Sul, Brazil. Neotropical Entomology 39:513-518.

Niklas KJ (1994) Plant allometry: the scaling of form and process. Chicago, The University of Chicago Press. 365p.

Nunes YRF, Fagundes M, Santos MR, Braga RF \& Gonzaga APD (2006) Germinação de sementes de Guazuma ulmifolia Lam. (Malvaceae) e Heteropterys byrsonimifolia A. Juss. (Malpighiaceae) sob diferentes tratamentos de escarificação tegumentar. Unimontes Científica, 8:43-52.

Oliveira-Filho AT, Scolforo JR \& Melo JM (1994) Composição florística e estrutura comunitária de um remanescente de Floresta Semidecídua Montana em Lavras (MG). Revista Brasileira de Botânica, 17:159-174.

Ribeiro Júnior PJ \& Diggle PJ (2001) GeoR: a package for geostatistical analysis. R-news, 1:15-18.

$\mathrm{R}$ development core team (2010) R: A Language and environment for statistical computing. Disponível em: <www.R-project.orgz. Acessado em: 15 de março de 2011. 
Root RB (1973) Organization of plant-arthropod association in a simple and diverse habitats: the fauna of collards (Brassica oleracea). Ecological Monographs, 43:95-124.

Santos JC, Carneiro MAA \& Fernandes GW (2012) Insetos galhadores neotropicais: diversidade e ecologia evolutiva dos herbívoros mais sofisticados da natureza. In: Del-Claro K \& Torezan-Silingardi HM (Eds.) Ecologia de Interações PlantasAnimais. Rio de Janeiro, Technical Books Editora. p.181-199.
Strong DRJ, Lawton JH \& Southwood TRE (1984) Insects on plants. Community patterns and mechanisms. Oxford, Blackwell. $313 \mathrm{p}$.

Van der Putten WH, Vet LEM, Harvey JA \& Wackers FL (2001) Linking above- and belowground multitrophic interactions of plants, herbivores, pathogens, and their antagonists. Trends in Ecology \& Evolution, 16:547-554. 